\title{
Relationship between smoking and antioxidant nutrient status
}

\author{
BY MD OMAR FARUQUE, MOUDUDUR RAHMAN KHAN, MD \\ MOSTAFIZUR RAHMAN AND FARUK AHMED* \\ Institute of Nutrition and Food Science, University of Dhaka, Dhaka-1000, Bangladesh
}

(Received 20 December 1993 - Revised 27 June 1994 - Accepted 21 July 1994)

\begin{abstract}
The present study was designed to investigate the relationship between smoking and antioxidant nutrient intake and status. Smoker $(n$ 44) and non-smoker $(n$ 44) male students attending Dhaka University, aged between 22 and 28 years and living in a University Hall of Residence, were selected for the present study. Mean age, body weight, BMI and blood pressure were similar for both the smokers and non-smokers. Mean energy, protein and fat intakes were similar for both groups. Smokers had lower intakes of dietary vitamin $\mathrm{C}$, carotenes and $\mathrm{Zn}$ but only the difference in $\mathrm{Zn}$ intake was statistically significant. There was no significant difference between smokers and non-smokers for either serum vitamin A (retinol) or vitamin $\mathbf{E}$ ( $\alpha$-tocopherol) level. The plasma vitamin $\mathrm{C}$ level of smokers was significantly lower than that of non-smokers $(P=0.0004)$. Smokers had significantly lower serum $\mathrm{Cu}(P=0.04)$ and higher serum $\mathrm{Zn}$ levels $(P=\mathbf{0 . 0 0 3})$. Further, a significant dose-response relationship between smoking and vitamin $C$ status was observed. Linear-regression analysis showed a significantly positive correlation between dietary intake and plasma vitamin $C$ values in non-smokers $(r 0.50 ; P=0.0005)$. On the contrary, no such association was observed in smokers. These findings suggest that smoking may cause an imbalance in antioxidant nutrient intake and status.
\end{abstract}

Smoking: Antioxidants: Vitamin C: Vitamin A: Vitamin E

Smoking has now been described as one of the major preventable causes of mortality and it accounts for more than one-third of all deaths in middle age in the UK (Secretary of State for Health, 1991). A large number of epidemiological studies have shown strong association between cigarette smoking and several diseases (Kannel, 1981; Libow \& Schlant, 1982; Shaper et al. 1985; Holbrook, 1987).

A number of studies have investigated the relationship between smoking and serum or plasma levels of antioxidant vitamins (Keith et al. 1980; Davis et al. 1983; Stryker et al. 1988; Bridges et al. 1990; Gregory et al. 1990; Herbeth et al. 1990; Bolton-Smith et al. 1991). However, the findings were not always consistent. Some studies have shown lower serum levels of $\beta$-carotene and vitamin A (Bridges et al. 1990), vitamin E (Gregory et al. 1990; Bolton-Smith et al. 1991) and vitamin C (Kallner et al. 1981; Smith \& Hodges, 1987; Schectman et al. 1989) in smokers. Many other studies did not show any difference in serum retinol or in serum total vitamin A (Stryker et al. 1988; Bolton-Smith et al. 1991) and serum $\alpha$-tocopherol levels (Keith et al. 1980) between smokers and non-smokers.

Studies in Western countries have indicated a different dietary pattern in smokers (Thompson et al. 1992), which may be one of several reasons for altered blood levels of the nutrients. Food habits and cultural and social environments of Asian people are different from those of Western people. It is not known how much influence these factors exert to change the dietary pattern of smokers observed in Western countries. The present study was designed to examine the relationship between smoking and dietary pattern in this different situation and also to investigate nutrient intake and status of the smokers.

$$
\text { * For reprints. }
$$




\section{METHODS AND MATERIALS}

The subjects were selected by advertisement at a Dhaka University male students' Hall of Residence. The volunteers who smoked six or more cigarettes per $d$ were considered smokers, and volunteers who never smoked were controls. Volunteers who took medication and multivitamin supplementation, or suffered from any chronic disease, were excluded from the study. All the smokers and the first forty-four of the non-smokers who met the selection criteria were included in the study. The subjects were residents of the Hall and aged between 22 and 28 years. Equal numbers of smokers and non-smokers were asked to report on a prearranged day. Body weight, height and general health information including blood pressure were recorded. Dietary information provided by the subjects was recorded using a $7 \mathrm{~d}$ food-frequency and amount questionnaire. Nutrient intakes were calculated using standard portion sizes (weights of portion sizes were taken from the canteen or mess of the Hall of Residence) and food-value tables (Institute of Nutrition and Food Science, 1992). Venous blood ( $5 \mathrm{ml}$ ) was withdrawn from the subject's arm. A $2.0 \mathrm{ml}$ portion was taken in a heparinized test-tube and centrifuged immediately for collection of plasma. An appropriate portion of the plasma was immediately mixed with trichloroacetic acid solution $(50 \mathrm{~g} / \mathrm{l})$ for estimation of vitamin $\mathrm{C}$. Following centrifugation, the supernatant fraction was separated and assayed on the same day. The rest of the blood sample was taken in an acid-washed glass centrifuge-tube and it was allowed to clot at room temperature for approximately $2 \mathrm{~h}$. After centrifugation, serum samples were frozen and stored at $-20^{\circ}$ until further analysis. For $\mathrm{Zn}$ and $\mathrm{Cu}$ analyses, serum samples were stored at $-20^{\circ}$ in separate ion-free vials.

The total serum protein and cholesterol were determined by Biuret and enzymiccolorimetric (cholesterol oxidase (EC 1.1.3.6)-peroxidase (EC 1.11.1.7)-aminophenazone) methods respectively using commercial kits (Boehringer Mannheim Diagnostic, Germany). Serum $\mathrm{Zn}$ and $\mathrm{Cu}$ concentrations were determined by atomic absorption spectrophotometry (Pye-Unicam SP9) according to Milner \& Whiteside (1981).

Plasma vitamin $\mathrm{C}$ was measured by the dinitrophenylhydrazine method according to Lowry et al. (1945). The CV was determined using ten replicates from a pooled sample and the value was $4 \cdot 0 \%$. Recovery of added vitamin $C$ was $90.3 \%$.

Serum retinol (vitamin A) and serum $\alpha$-tocopherol (vitamin E) concentrations were determined simultaneously by HPLC according to Bieri et al. (1979). In brief, serum vitamins $\mathrm{A}$ and $\mathrm{E}$ were extracted with hexane after deproteinization with absolute ethanol containing retinyl acetate and $\alpha$-tocopherol acetate (Sigma Chemical Co., St Louis, MO, USA) as internal standards for vitamins $A$ and $E$ respectively. Retinol and $\alpha$-tocopherol were separated by HPLC (model PU 4010; Pye-Unicam) on a reversed-phase $\mathrm{C}_{18}$ column (Spherisorb $5 \mu \mathrm{m}$ octadecylsilyl, Pye-Unicam) using methanol-water $(97 \cdot 5: 2 \cdot 5, \mathrm{v} / \mathrm{v}$ ) as the mobile phase. Elution was detected spectrophotometrically (model PU 4020; Pye-Unicam) and $A_{291 n m}$ was recorded on a single-pen recorder (model PM 8251; Pye-Unicam). CV values of ten replicates from a pooled serum sample for retinol and $\alpha$-tocopherol were $2 \cdot 3$ and $3 \cdot 3 \%$ respectively.

The normality of the distributions of the data was assessed using the KolmogorovSmirnov goodness-of-fit test. Differences between smokers and non-smokers for dietary pattern were assessed using the unpaired $t$ test. One-way analysis of variance was used to assess nutrient intake and status. Linear-regression analysis was performed to assess the association between vitamin $\mathrm{C}$ intake and plasma levels by smoking groups. Data were analysed using Statistical Package for Social Sciences (1990). 
Table 1. Mean number of portions of selected food items consumed by male students at the University of Dhaka, Bangladesh, who were smokers and non-smokers*

(Mean values with their standard errors, medians and ranges)

\begin{tabular}{|c|c|c|c|c|c|c|c|c|c|}
\hline \multirow{2}{*}{$\begin{array}{l}\text { Food items } \\
\text { (portions/week) }\end{array}$} & \multicolumn{4}{|c|}{ Smoker } & \multicolumn{4}{|c|}{ Non-smoker } & \multirow{2}{*}{$\begin{array}{c}\text { Statistical } \\
\text { significance } \\
\text { of difference } \\
\text { between } \\
\text { groups: } \\
P^{\dagger}\end{array}$} \\
\hline & Mean & $\mathbf{S E}$ & Median & Range & Mean & SE & Median & Range & \\
\hline Meat & $7 \cdot 7$ & 0.5 & 7.0 & $2-14$ & $6 \cdot 8$ & 0.5 & $7 \cdot 0$ & $1-19$ & $0 \cdot 17$ \\
\hline Fish & $5 \cdot 8$ & 0.4 & $5 \cdot 0$ & $0-14$ & $6 \cdot 7$ & 0.4 & $7 \cdot 0$ & $0-13$ & $0 \cdot 18$ \\
\hline Egg (pieces/week) & $5 \cdot 3$ & 0.5 & 5.0 & $0-12$ & $4 \cdot 1$ & 0.5 & 4.0 & $0-15$ & 0.08 \\
\hline Leafy vegetables & $2 \cdot 7$ & $0-3$ & $2 \cdot 0$ & $0-09$ & $2 \cdot 4$ & 0.2 & $2 \cdot 0$ & $0-07$ & 0.41 \\
\hline Fruits & $13 \cdot 5$ & $1 \cdot 8$ & $10 \cdot 9$ & $2-63$ & $12 \cdot 8$ & $1 \cdot 3$ & $10-2$ & $2-36$ & 0.77 \\
\hline Tea (cups/week) & $16 \cdot 8$ & $1 \cdot 8$ & 17.0 & $0-56$ & $5 \cdot 8$ & 1.0 & $5 \cdot 0$ & $0-21$ & 0.0005 \\
\hline
\end{tabular}

* For details of subjects and procedures, see p. 626.

$\uparrow$ Calculated using unpaired $t$ test.

\section{RESULTS}

Mean age and BMI of smokers were $24 \cdot 7$ (SE 0.2) years and $19 \cdot 7$ (SE 0.3) $\mathrm{kg} / \mathrm{m}^{2}$ respectively and for the non-smokers were 24.8 (SE 0.2 ) years and 20.0 (SE 0.4$) \mathrm{kg} / \mathrm{m}^{2}$ respectively. Differences between the groups were not statistically significant. The mean values for systolic blood pressure of smokers and non-smokers were 115.0 (SE 1.1) and 112.5 (SE 1.5) $\mathrm{mmHg}$ respectively, and those for the diastolic blood pressure were 73.0 (SE 1.2) and $72 \cdot 1$ (SE 1.2) $\mathrm{mmHg}$ respectively. The values were not significantly different.

Unpaired $t$ tests were carried out to examine differences in consumption of selected food items by the two groups. The results are presented in Table 1. There were no significant differences in consumption of meat, fish, eggs, leafy vegetables and fruits by smokers and non-smokers. Smokers were found to consume significantly higher amounts of beverages (tea) compared with the non-smokers $(P=0.0005)$.

Table 2 shows the nutrient intake and serum or plasma levels of both smokers and nonsmokers. There were no significant differences in energy, protein, fat, carotene and retinol intakes. Vitamin $C$ intake by the smokers was found to be lower than that of the nonsmokers; the difference was not statistically significant $(P=0 \cdot 19)$. The $\mathrm{Zn}$ intake of the smokers was significantly lower than that of non-smokers $(P=0.04)$. Serum total protein, cholesterol, retinol (vitamin A) and $\alpha$-tocopherol (vitamin E) levels were not significantly different between the groups. Plasma vitamin $\mathrm{C}$ level of smokers was significantly lower than that of non-smokers $(P=0.0004)$. Smokers had significantly higher serum $\mathrm{Zn}(P=$ $0.003)$ and lower serum $C u$ levels $(P=0.04)$.

The antioxidant nutrients whose intakes and/or serum levels in the smokers were different from those in the non-smokers were further analysed for dose-response relationship with smoking habit. The smokers were divided into two groups: mild smokers (those who smoked up to nine cigarettes per d) and heavy smokers (those who smoked ten or more cigarettes per d). The data are presented in Table 3. There was no significant difference in vitamin $\mathrm{C}$ intake between the various smoking groups. Further, no significant difference was observed in $\mathrm{Zn}$ intakes for heavy and mild smokers $(P=0 \cdot 13)$. Plasma vitamin $\mathrm{C}$ level was lowest in heavy smokers, highest in non-smokers and mild smokers had an intermediate level. The difference was highly significant $(P=0.0005)$. Non-smokers had a 
Table 2. Energy and nutrient intake and serum or plasma levels of male students at the University of Dhaka, Bangladesh, who were smokers and non-smokers*

(Mean values with their standard errors for forty-four subjects per group)

\begin{tabular}{|c|c|c|c|c|c|}
\hline \multirow[b]{2}{*}{ Variable } & \multicolumn{2}{|c|}{ Smoker } & \multicolumn{2}{|c|}{ Non-smoker } & \multirow{2}{*}{$\begin{array}{c}\text { Statistical } \\
\text { significance } \\
\text { of difference } \\
\text { between } \\
\text { groups: } \\
P \dagger\end{array}$} \\
\hline & Mean & $\mathrm{SE}$ & Mean & $\mathrm{SE}$ & \\
\hline Energy $(\mathrm{kJ} / \mathrm{d})$ & 10129 & 249 & 10686 & 293 & 0.15 \\
\hline \multicolumn{6}{|l|}{ Dietary nutrient intake } \\
\hline Protein $(\mathrm{g} / \mathrm{d})$ & $80 \cdot 8$ & $2 \cdot 4$ & $83 \cdot 1$ & $2 \cdot 2$ & 0.48 \\
\hline Fat $(g / d)$ & $51 \cdot 0$ & $1 \cdot 3$ & $50 \cdot 0$ & 1.9 & 0.68 \\
\hline Carotene $(\mu \mathrm{g} / \mathrm{d})$ & 4726 & 418 & 6111 & 610 & 0.06 \\
\hline Retinol $(\mu \mathrm{g} / \mathrm{d})$ & 275 & 58 & 196 & 30 & 0.23 \\
\hline Vitamin $\mathrm{C}(\mathrm{mg} / \mathrm{d})$ & $70 \cdot 4$ & 6.4 & 83.4 & 7.5 & 0.19 \\
\hline $\mathrm{Zn}(\mathrm{mg} / \mathrm{d})$ & $11 \cdot 1$ & 0.3 & 12.0 & 0.3 & 0.04 \\
\hline \multicolumn{6}{|l|}{ Serum } \\
\hline Protein $(\mathrm{g} / \mathrm{l})$ & $76 \cdot 0$ & 0.7 & $76 \cdot 5$ & 0.5 & 0.53 \\
\hline Cholesterol (mM) & 3.8 & 0.1 & 3.5 & 0.1 & 0.12 \\
\hline Vitamin $\mathrm{E}:$ cholesterol $(\mu \mathrm{M} / \mathrm{mM})$ & $3 \cdot 8$ & $0 \cdot 1$ & $3 \cdot 9$ & 0.2 & 0.59 \\
\hline Retinol $(\mu \mathrm{g} / \mathrm{l})$ & 558 & 23 & 535 & 20 & 0.42 \\
\hline Vitamin $\mathrm{E}(\mathrm{mg} / \mathrm{l})$ & 0.62 & 0.02 & 0.59 & 0.04 & 0.48 \\
\hline $\mathrm{Cu}(\mu \mathrm{g} / \mathrm{l})$ & 874 & 25 & 952 & 28 & 0.04 \\
\hline $\operatorname{Zn}(\mu \mathrm{g} / \mathrm{l})$ & 796 & 18 & 722 & 16 & 0.003 \\
\hline \multicolumn{6}{|l|}{ Plasma } \\
\hline Vitamin C (mg/l) & 3.9 & 0.2 & $5 \cdot 3$ & $0 \cdot 3$ & 0.0004 \\
\hline
\end{tabular}

* For details of subjects and procedures, see p. 626.

$\dagger$ Calculated using one-way analysis of variance.

Table 3. Dose-response relationship between smoking and selected antioxidant nutrient intake and serum or plasma levels of male students at the University of Dhaka, Bangladesh*

(Mean values with their standard errors)

\begin{tabular}{|c|c|c|c|c|c|c|c|}
\hline \multirow{2}{*}{$\begin{array}{l}n \ldots \\
\text { Variable }\end{array}$} & \multicolumn{2}{|c|}{$\begin{array}{c}\text { Non-smoker } \\
\text { (44) }\end{array}$} & \multicolumn{2}{|c|}{$\begin{array}{l}\text { Mild smoker } \dagger \\
\qquad(28)\end{array}$} & \multicolumn{2}{|c|}{$\begin{array}{c}\text { Heavy smoker } \dagger \\
(16)\end{array}$} & \multirow{2}{*}{$\begin{array}{c}\text { Statistical } \\
\text { significance } \\
\text { of difference } \\
\text { between } \\
\text { groups: } \\
P \ddagger\end{array}$} \\
\hline & Mean & $\mathrm{SE}$ & Mean & SE & Mean & SE & \\
\hline \multicolumn{8}{|l|}{ Dietary } \\
\hline Vitamin C $(\mathrm{mg} / \mathrm{d})$ & $83 \cdot 4$ & $7 \cdot 5$ & $75 \cdot 4$ & $8 \cdot 3$ & $61 \cdot 7$ & $9 \cdot 9$ & 0.27 \\
\hline $\mathrm{Zn}(\mathrm{mg} / \mathrm{d})$ & $12 \cdot 0$ & $0 \cdot 3$ & $11 \cdot 1$ & 0.4 & $11 \cdot 1$ & $0 \cdot 4$ & 0.13 \\
\hline \multicolumn{8}{|l|}{ Serum } \\
\hline $\mathrm{Zn}(\mu \mathrm{g} / 1)$ & $722 \cdot 3$ & $15 \cdot 5$ & $789 \cdot 1$ & 24.8 & $806 \cdot 6$ & $24 \cdot 8$ & 0.01 \\
\hline $\mathrm{Cu}(\mu \mathrm{g} / 1)$ & $952 \cdot 4$ & $27 \cdot 8$ & $900 \cdot 6$ & $34 \cdot 4$ & $828 \cdot 6$ & $33 \cdot 7$ & 0.06 \\
\hline \multicolumn{8}{|l|}{ Plasma } \\
\hline Vitamin C (mg/l) & $5-3$ & $0 \cdot 3$ & $4 \cdot 2$ & $0 \cdot 3$ & $3 \cdot 3$ & $0 \cdot 3$ & 0.0005 \\
\hline
\end{tabular}

* For details of subjects and procedures, see p. 626.

+ Mild smoker, smoked up to nine cigarettes per d; heavy smoker, smoked ten or more cigarettes per d.

\$Calculated using one-way analysis of variance. 

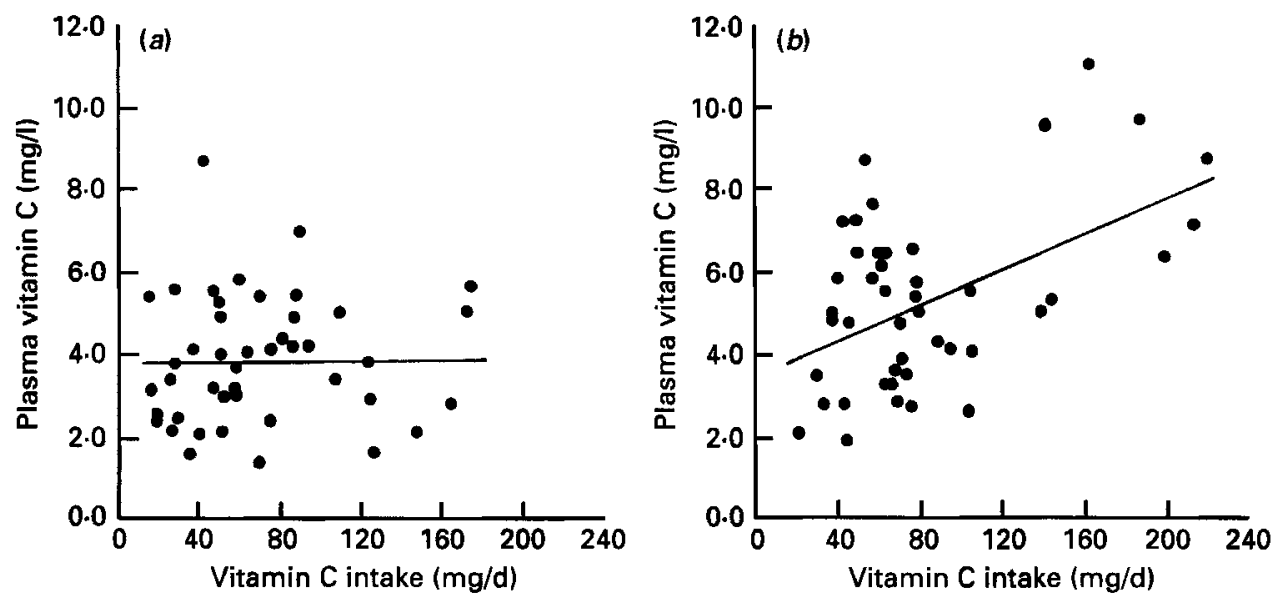

Fig. 1. Relationship between dietary intake and plasma vitamin $C$ level of male students at the University of Dhaka, Bangladesh, who were $(a)$ smokers and $(b)$ non-smokers. For details of subjects and procedures, see p. 626 . (a) $y=3.8+0.002 x r 0.05, P=0.73 ;(b) y=3.6+0.02 x+0.50, P=0.0005$.

significantly lower serum $\mathrm{Zn}$ concentration than either mild or heavy smokers $(P=0.01)$. But the difference between mild and heavy smokers was not significant. No significant difference was observed in serum $\mathrm{Cu}$ level between mild and heavy smokers $(P=0.06)$.

Linear-regression analysis was performed on dietary vitamin $C$ intake and plasma vitamin $\mathrm{C}$ level of both smokers and non-smokers. A significant positive correlation between dietary intake and plasma vitamin $\mathrm{C}$ value was observed in the non-smokers $(r 0.50 ; P=0.0005)$, but no such relationship was found in the smokers (Fig. 1 ).

\section{DISCUSSION}

The present study was carried out to investigate the relationship between smoking and antioxidant nutrient intake and status. Several personal factors such as age, sex, BMI, socio-economic status, medication and vitamin supplementation are known to influence plasma antioxidant nutrient levels (Friedman et al. 1986; Comstock et al. 1987; Nierenberg et al. 1989; Bolton-Smith et al. 1991; Ahmed et al. 1992). Effects of these various potentially confounding factors were minimal in our subjects as they were all young males, had similar age, body weight, BMI, blood pressure and socio-economic background.

Several reports in Western countries have indicated a relationship between cigarette smoking and a change in dietary pattern and nutrient intake (Whichelow, 1989; Gregory et al. 1990; Larkin et al. 1990; Whichelow \& Erzinglioglu, 1990; Bolton-Smith et al. 1991; Cade \& Margetts, 1991). Unlike in Western countries, there is a limited choice of food items in a country like Bangladesh and the choice is even more limited in the mess rooms or canteens of the University Halls of Residence.

Although there was no significant difference between smokers and non-smokers in their consumption of various selected food items with the exception of tea, it was apparent that a relatively higher percentage of smokers took eggs more frequently and fish less frequently (values not shown). A similar dietary pattern for smokers has been reported by other investigators (Larkin et al. 1990; Suber et al. 1990). In contrast to the findings in Western countries, there was no difference in the frequency of meat intake. A large proportion of 
both the smokers and non-smokers did not consume vegetables. Among those who consumed leafy vegetables there was little difference in the frequency of intake, in contrast to the findings of previous workers (Larkin et al. 1990; Suber et al. 1990). In the present study a greater number of non-smokers consumed seasonal fruits, such as guava, mango, pineapple and jackfruit (Artocarpus heterophylla), while smokers ate bananas more frequently (values not shown). Near the University Halls of Residence, bananas are usually sold at small tea stalls where cigarettes are also available, which may be a reason for a higher intake by the smokers. The mean consumption of fruit by the two groups was not significantly different. On the other hand, Western investigators observed a lower intake of fruit by smokers (Whichelow, 1989; Larkin et al. 1990; Whichelow \& Erzinglioglu, 1990). The disagreement may be due to the higher intake of bananas by smokers. A number of studies have reported a higher consumption of beverages by smokers (Whichelow et al. 1988; Larkin et al. 1990; Whichelow \& Erzinglioglu, 1990), as was found in our study. The present study, thus, indicates a tendency towards a different dietary pattern in smokers, even within a limited choice of food items.

To assess the energy and nutrient intake of the participants, each portion of the food items served in the canteen or the mess room of the Hall of Residence was weighed for a period of 3 consecutive days. The nutrient intake was then calculated from the nutrient values for the cooked food. Retinol intake for smokers was not significantly different from that for non-smokers, in agreement with Western studies (Gregory et al. 1990; BoltonSmith et al. 1991; Cade \& Margetts, 1991). We found no significant difference in carotene intake between smokers and non-smokers, similar to the finding of Stryker et al. (1988). On the other hand, other studies have shown a significantly lower intake of dietary carotene by smokers (Bolton-Smith et al. 1991; Cade \& Margetts, 1991). The present study does not provide any information about vitamin $\mathrm{E}$ intake as no information on vitamin $\mathrm{E}$ content of Bangladeshi foodstuffs is available.

Serum retinol levels of smokers were not significantly different from those of nonsmokers; this is in agreement with previous findings (Davis et al. 1983; Bolton-Smith et al. 1991). The reports on the relationship between smoking and serum vitamin $E$ have been contradictory. Keith et al. (1980) observed no significant differences in serum $\alpha$-tocopherol concentrations between smokers and non-smokers, similar to our finding. On the other hand, a significantly lower level of serum vitamin $\mathrm{E}$ in smokers was reported by BoltonSmith et al. (1991).

Plasma vitamin C levels of smokers were significantly lower than those of non-smokers. This finding confirms the relationship between cigarette smoking and decreased plasma vitamin C level reported in the previous studies (Schectman et al. 1989; Bridges et al. 1990; Bolton-Smith et al. 1991). Further, a dose-response relationship was observed between smoking and plasma vitamin C level, similar to the finding of Schectman et al. (1989). Plasma vitamin C levels of the smokers were $26 \%$ lower than those of the non-smokers, while their dietary intake was $16 \%$ lower. This discrepancy indicates an effect of smoking on plasma vitamin $\mathrm{C}$ level which may not be accounted for by the difference in dietary intake alone. Schectman et al. (1989) suggested that the effect of cigarette smoking on serum vitamin $\mathrm{C}$ levels might occur via a process other than decreased dietary vitamin $\mathrm{C}$ consumption. We also assessed the relationship between intake and the plasma vitamin $\mathrm{C}$ level in both smokers and non-smokers using linear-regression analysis. In non-smokers a significant positive relationship was observed between dietary intake and plasma vitamin $\mathrm{C}$ level. Interestingly, such a relationship was absent in the smokers. However, some caution needs to be used before drawing a generalized conclusion, as there appears to be a discontinuity of data-points in the plot for the non-smokers and consequently the relationship is dependent on six high-intake individuals. 
The findings support the contention of previous investigators that smoking is related to either decreased absorption or increased turnover of vitamin C (Pelletier, 1970; Kallner et al. 1981). We do not know at this stage whether the absence of a relationship between dietary intake and plasma levels of vitamin $\mathrm{C}$ in smokers was due to malabsorption or increased turnover or a combined effect of both. This is an important point to be resolved in future studies.

We observed significantly higher serum $\mathrm{Zn}$ levels and lower serum $\mathrm{Cu}$ levels in smokers compared with non-smokers. Both of these variables, however, are affected by inflammation and are not considered to be reliable indicators of status in human populations (Sinha \& Gabrieli, 1970; Beisel, 1977).

The present study shows a depressed antioxidant nutrient status of the smokers which may be due to both their aberrant dietary habit and the increased demand placed on the antioxidants by cigarette smoke itself. The increased free-radical load incurred by smoking and lower intake of antioxidant nutrients may shift the normal free-radical-antioxidant balance in the body with initiation of a deterioration process and, thereby, increase the risk of atherosclerotic and other diseases.

The authors are indebted to the University of Dhaka, Dhaka, Bangladesh for financial support to the study. The authors also express their sincere thanks to the participants of this study.

\section{REFERENCES}

Ahmed, F., Mohiduzzaman, M., Barua, S., Shaheen, N., Margetts, B. M. \& Jackson, A. A. (1992). Effect of family size and income on the biochemical indices of urban school children of Bangladesh. European Journal of Clinical Nutrition 46, 465-473.

Beisel, W. R. (1977). Zinc metabolism in infection. In Zinc Metabolism, pp. 155-164 [G. J. Brewer and A. S. Prasad, editors]. New York: Alan Liss Inc.

Bieri, J. G., Tolliver, T. J. \& Catignani, G. L. (1979). Simultaneous determination of alpha-tocopherol and retinol in plasma or red cells by high pressure liquid chromatography. American Journal of Clinical Nutrition 32 , 2143-2149.

Bolton-Smith, C., Casey, C. E., Gay, K. F., Smith, W. C. S. \& Tunstall-Pedoe, H. (1991). Antioxidant vitamin intakes assessed using a food-frequency questionnaire: correlation with biochemical status in smokers and nonsmokers. British Journal of Nutrition 65, 337-346.

Bridges, R. B., Chow, C. K. \& Rehm, S. R. (1990). Micronutrient status and immune function in smokers. Annals of the New York Academy of Sciences 587, 218-231.

Cade, J. \& Margetts, B. M. (1991). The relationship between diet and smoking: is the diet of smokers different? Journal of Epidemiology and Community Health 45, 270-272.

Comstock, G. W., Menkes, M. S., Schober, S. E., Vuilleumier, J.-P. \& Helsing, K. J. (1987). Serum levels of retinol, beta-carotene and alpha-tocopherol in older adults. American Journal of Epidemiology 127, 114-123.

Davis, C., Brittain, E., Hunninghake, D., Graves, K., Buzzard, M. \& Tyroler, H. (1983). Relation between cigarette smoking and serum vitamin $\mathrm{A}$ and carotene in candidates for the lipid research clinics coronary prevention trial. American Journal of Epidemiology 118, 445 Abstr.

Friedman, G. D., Blaner, W. S., Goodman, D. S., Vogelman, J. H., Brind, J. L., Hoover, R., Fireman, B. H. \& Orentreich, N. (1986). Serum retinol and retinol binding protein levels do not predict subsequent lung cancer. American Journal of Epidemiology 123, 781-789.

Gregory, J., Foster, K., Tyler, H. \& Wiseman, M. (1990). The Dietary and Nutritional Survey of British Adults. London: H.M. Stationery Office.

Herbeth, B., Chavance, M., Musse, N., Mejean, L. \& Vernhes, G. (1990). Determinants of plasma retinol, $\beta$ carotene and $\alpha$-tocopherol. American Journal of Epidemiology 132, 394-396.

Holbrook, J. H. (1987). Tobacco. In Harrison's Principles of Internal Medicine 1, 11th ed., pp. $855-859$ [E. Braunwald, K. J. Isselbacher, R. G. Petersdorf, J. D. Wilson, J. B. Martin and A. C. Fauci, editors]. New York: McGraw-Hill Book Company.

Institute of Nutrition and Food Science (1992). Deshia Khadyadrabyer Pushtiman (Nutritive Value of Indigenous Foodstuffs). Dhaka, Bangladesh: University of Dhaka.

Kallner, A. B., Hartmann, D. \& Hormig, D. H. (1981). On the requirements of ascorbic acid in men: steady state turnover and body pool in smokers. American Journal of Clinical Nutrition 34, 1347-1355.

Kannel, W. B. (1981). Update on the role of cigarette smoking in coronary artery disease. American Heart Journal $101,319-328$. 
Keith, R. E., Chrisley, B. M. \& Driskell, J. A. (1980). Dietary vitamin C supplementation and plasma vitamin E levels in humans (letter). American Journal of Clinical Nutrition 33, $2394-2395$.

Larkin, F. A., Basiotis, P. P., Riddick, H. A., Sykes, K. E. \& Pao, E. M. (1990). Dietary patterns of women smokers and non-smokers. Journal of the American Dietetic Association 90, 230-236.

Libow, M. \& Schlant, R. C. (1982). Smoking and heart disease. In Progress in Cardiology, vol. 11, pp. 131-161 [P. N. Yu and J. F. Goodwin, editors]. Philadelphia: Lea and Febiger.

Lowry, O. H., Lopez, J. A. \& Bessey, O. A. (1945). The determination of ascorbic acid in small amount of blood serum. Journal of Biological Chemistry 160, 609-615.

Milner, B. A. \& Whiteside, P. J. (1981). Introduction to Atomic Absorption Spectrophotometry, 2nd ed. Cambridge: Pye Unicam Ltd.

Nierenberg, D. W., Stukel, T. A., Baron, J. A., Dain, B. J., Greenberg, E. R. \& The Skin Cancer Prevention Study Group (1989). Determinants of plasma levels of $\beta$-carotene and retinol. American Journal of Epidemiology 130, 511-521.

Pelletier, O. (1970). Vitamin C status of cigarette smokers and non-smokers. American Journal of Clinical Nutrition 23, $1347-1355$.

Schectman, G., Byrd, J. C. \& Gruchow, H. W. (1989). The influence of smoking on vitamin C status in adults. American Journal of Public Health 79, 158-162.

Secretary of State for Health (1991). Health of the Nation. London: H.M. Stationery Office.

Shaper, A. G., Pocock, S. J., Walker, M., Phillips, A. N., Whitehead, T. P. \& MacFarlane, P. W. (1985). Risk factors for ischaemic heart disease: the prospective phase of the British Regional Heart Study. Journal of Epidemiology and Community Health 39, 197-209.

Sinha, S. N. \& Gabrieli, E. R. (1970). Serum copper and zinc levels in various pathologic conditions. American Journal of Clinical Pathology 54, 570-577.

Smith, J. L. \& Hodges, R. E. (1987). Serum levels of vitamin C in relation to dietary and supplemental intake of vitamin $\mathrm{C}$ in smokers and non-smokers. Annals of the New York Academy of Sciences 498, 144-152.

Statistical Package for Social Sciences (1990). SPSS/PC+Version 4.0. Chicago, Il. : SPSS Inc.

Stryker, W. S., Kaplan, L. A., Stein, E. A., Stampfer, M. J., Sober, A. \& Willett, W. C. (1988). The relation of diet, cigarette smoking and alcohol consumption to plasma $\beta$-carotene and $\alpha$-tocopherol levels. American Journal of Epidemiology 127, 283-296.

Suber, A. F., Linda, R. D., Harlan, C. \& Mattson, M. E. (1990). Food and nutrient intake differences between smokers and non-smokers in the United States. American Journal of Public Health 80, 1323-1329.

Thompson, R. L., Margetts, B. M., Wood, D. A. \& Jackson, A. A. (1992). Cigarette smoking and food and nutrient intakes in relation to coronary heart disease. Nutrition Research Reviews 5, 131-152.

Whichelow, M. J. (1989). Choice of spread by a random sample of the British population. European Journal of Clinical Nutrition 43, 1-10.

Whichelow, M. J. \& Erzinglioglu, S. W. (1990). Comparison of the diets of smokers and non-smokers. Proceedings of the Nutrition Society 49, 42A.

Whichelow, M. J., Golding, J. F. \& Treasure, F. P. (1988). Comparison of some dietary habits of smokers and non-smokers. British Journal of Addiction 83, 295-304. 